\title{
Correction to: Class in the USA
}

\section{Paul Durrenberger ${ }^{1,2} \cdot$ Dimitra Doukas $^{2}$}

Published online: 23 January 2018

(C) Springer Science+Business Media B.V., part of Springer Nature 2018

\section{Correction to: Dialect Anthropol \\ https://doi.org/10.1007/s10624-017-9479-0}

The original version contained a mistake. Under The fall of labor heading, the correct sentence is ".. a process that continues to the time of this writing as a series of Republican state governors attempt to obliterate public workers' unions". The original article has been corrected.

The online version of the original article can be found at https://doi.org/10.1007/s10624-017-9479-0

Paul Durrenberger epd2@psu.edu

1 University of Iowa, 1398 Franklin Ave, West Branch, IA 52358, USA

26992 Poco Bueno Circle, Sparks, NV 89436, USA 